\title{
IDENTIFICATION AND MOLECULAR CHARACTERIZATION OF BACTERIA HAVING ANTIMICROBIAL AND ANTIBIOFILM ACTIVITY
}

\author{
GARIMA SHARMA, SHWETA DANG, SANJAY GUPTA, REEMA GABRANI* \\ Department of Biotechnology, Jaypee Institute of Information Technology, A-10, Sector 62, NOIDA, India \\ Email: reema.gabrani@jiit.ac.in
}

Received: 22 Apr 2016 Revised and Accepted: 12 Aug 2016

\section{ABSTRACT}

Objective: The aim of the current study was to isolate and identify the bacteriocinogenic strain exhibiting broad range antimicrobial activity and antibiofilm activity from the soil of animal farms.

Methods: In the current study, bacterial strains were isolated from soil of twelve different regions of the animal farm all over India and screened for antimicrobial activity against Staphylococcus epidermidis, Micrococcus luteus, Pseudomonas fluorescence and Escherichia coli. Antibiofilm ability of these selected strains was checked on preformed biofilm of $S$. epidermidis and in addition biofilm disruption potential was also determined. The potent bacterial strain was identified at the molecular level by 16 S ribosomal DNA (rDNA) sequencing

Results: 30 out of 231 strains isolated from soil were selected on the basis of antibacterial activity against S. epidermidis. One potential candidate (GAS 101) exhibited $\geq 99 \%$ inhibition against S. epidermidis, M. luteus, P. fluorescence and E. coli and also showed antibiofilm activity. GAS $10116 \mathrm{~S}$ rDNA sequencing data identified it as Bacillus subtilis. The sequence of B. subtilis was submitted to genbank under accession no. KJ564301.

Conclusion: B. subtilis GAS 101 isolated from soil of animal farm showed the antibacterial activity against all indicator organisms and also displayed antibiofilm activity against preformed biofilm and inhibited biofilm formation of $S$. epidermidis.

Keywords: B. subtilis, E. coli, M. luteus, P. fluorescence, S. epidermidis

(C) 2016 The Authors. Published by Innovare Academic Sciences Pvt Ltd. This is an open access article under the CC BY license (http://creativecommons. org/licenses/by/4. 0/) DOI: http://dx.doi.org/10.22159/ijpps.2016v8i10.12338

\section{INTRODUCTION}

Bacterial nosocomial infections can pose a major risk mainly in immune-compromised patients. Advancement in medical sciences has led to the increased use of invasive devices resulting in high rates of infection [1]. Bacteriocins are ribosomally synthesized peptides which bacteria use as their natural defense mechanism in the same niche area. Bacteriocins have many properties like low toxicity, potency, narrow and broad spectrum effectiveness and in situ production. These properties indicate that bacteriocin can be used as alternate to antibiotic [2]. Production of bacteriocin is widespread in nature; a single bacterial species has been reported to produce 10 to 100 different types of bacteriocins [3]. Lactic acid bacteria (LAB) and Bacillus species both have gained the focus because of the ability to produce broad-spectrum inhibitory activity and GRAS status by the US FDA. Nisin and pediocin are the most studied antimicrobial substance from LAB which are commonly used in food production industry as a preservative agent and in the pharmaceutical industry as a health care product $[4,5]$.

An antimicrobial substance produced by Bacillus species may be placed on the second place after LAB because of the diversity in the antimicrobial peptide (AMP) due to different chemical structures [6]. The Bacillus subgroup has been reported to produce a large number of AMPs and this can be a good source to explore the novel antimicrobial substances [7, 8]. Subtilin synthesized by B. subtilis is a cationic AMP which belongs to lantibiotic and has been studied extensively. It has been shown to be active against broad spectrum gram positive bacteria and acts via pore formation [9]. A number of reported bacteriocins is very less as compared to the reported bacterial species, so necessitating a need to explore the properties and therapeutic applications of bacteriocins. The objective of the current study was to isolate the bacteria producing antimicrobial substance from soil of animal farm. The soil is a rich source of microorganisms, as it provides an enhanced environment for the growth of microbes, which contributes towards enormous diversity of bacteria. In the current study, we have isolated different microbes which are able to produce antimicrobial substances from the soil of animal farm using de
Man, Rogosa and Sharpe (MRS) agar plates. The isolate that possessed the broad activity against indicator organisms and was able to disrupt biofilm was further identified by molecular characterization.

\section{MATERIALS AND METHODS}

\section{Chemicals}

The Chemicals and media used in the current study were procured from Hi-Media, CDH and Sigma-Aldrich.

\section{Methods}

Bacterial strains and growth conditions

Four different microorganisms $S$. epidermidis (MTCC no. 435), $P$ fluorescence (MTCC No. 2421), M. luteus (MTCC No. 106) and E. col (MTCC No. 443) used in the current study were procured from MTCC, Chandigarh. All bacteria were cultured in nutrient broth at 37 ${ }^{\circ} \mathrm{C}$ for $16-18 \mathrm{~h}$

Isolation of antimicrobial substance producing bacteria from soil of animal farm

Bacterial strains were isolated from soil collected near the dairy of the various region of India (table 1). One gram of soil was mixed with $9 \mathrm{ml}$ of autoclaved distilled water, homogenized using a vortex mixture and serially diluted with autoclaved water. Subsequently, $100 \mu \mathrm{l}$ of each dilution was spread onto MRS agar plate (Hi-media) and the plates were incubated at $30{ }^{\circ} \mathrm{C}$ for $24 \mathrm{~h}$. Well-isolated colonies were inoculated into fresh MRS broth for stock preparation.

Inhibition spectrum of cell free supernatant (CFS) of isolated bacterial strains

The inhibition spectrum of each isolate was examined using the 96 well microtiter plate assay against indicator organisms. The supernatant was obtained by centrifugation $(10,000 \times \mathrm{g}, 15 \mathrm{~min}$ at 4 ${ }^{\circ} \mathrm{C}$ ) of culture grown in MRS broth at $30^{\circ} \mathrm{C}$ for $24 \mathrm{~h}$. CFS from overnight grown culture was incubated with the $1 \times 10^{6} \mathrm{cfu} / \mathrm{ml}$ of the indicator organisms in each well of the 96 well plates [10]. Three wells in each 
plate served as sterility control (without inoculum). Plates were incubated at $37{ }^{\circ} \mathrm{C}$ for $16-18 \mathrm{~h}$ and then examined for the growth inhibition with respect to control (indicator organism without CFS). The assay was carried out in triplicates and repeated thrice.

\section{Determination of activity unit per $\mathrm{ml}(\mathrm{AU} / \mathrm{ml})$}

Antimicrobial activity $(\mathrm{AU} / \mathrm{ml})$ was expressed as the reciprocal of the highest dilution that gave a definite zone of inhibition multiplied by a dilution factor [11]. $1 \times 10^{6} \mathrm{cfu} / \mathrm{ml}$ of $S$. epidermidis was treated with the 1:2-1:128 dilution of the CFS from each isolate and incubated at $37{ }^{\circ} \mathrm{C}$ for $16-18 \mathrm{~h}$. The highest dilution showing inhibition activity was considered as antimicrobial activity unit.

\section{Antibiofilm activity of cell-free supernatant}

CFS from each isolate was tested for its potential antibiofilm activity against preformed S. epidermidis biofilm and also on its biofilm formation.

\section{Inhibition of cell attachment}

CFS from each isolate was incubated with $1 \times 10^{6} \mathrm{cfu} / \mathrm{ml}$ of $S$. epidermidis in the 96 well plate and incubated at $37^{\circ} \mathrm{C}$ for $48 \mathrm{~h}$ to allow cell attachment and biofilm development. The plate was washed with phosphate buffer saline (PBS) and the crystal violet staining assay was performed [12]. Evaluation of \% reduction in biofilm was evaluated by-

$$
\% \text { inhibition }=\left[1-\left(\frac{\text { absorbance of treated bacteria }}{\text { absorbance of untreated bacteria }}\right)\right] \times 100
$$

\section{Reduction of biofilm growth and development}

The plates containing $1 \times 10^{6} \mathrm{cfu} / \mathrm{ml}$ of $S$. epidermidis were incubated at $37^{\circ} \mathrm{C}$ for $48 \mathrm{~h}$ to allow cell attachment and biofilm development.
The wells were properly washed after incubation with PBS to remove unbound cells. CFS from each isolate was added to the well and further incubated for $24 \mathrm{~h}$. The plate was washed with PBS and crystal violet assay was performed as discussed above.

Molecular characterization and phylogenetic analysis of $16 \mathrm{~S}$ rDNA sequence of potential strain

Genomic DNA of the selected strain was isolated by cetyltrimethylammonium bromide (CTAB) method according to Cullings et al. 1992 [13]. The 16S rDNA of the strain (GAS 101) was amplified using universal primers 8-27F AGAGTTTGATCCTGGCTCAG and 1492R GGTTACCTTGTTACGACTTC; the sequence was submitted to Genbank (accession no. KJ564301). The phylogenetic tree of the amplified sequence of $16 \mathrm{~S}$ rDNA of B. subtilis strains GAS101 with closely related Bacillus species was constructed by CLUSTAL W software.

\section{RESULTS}

\section{Isolation of bacterial strains possessing antimicrobial activity}

The isolation of bacterial strains from soil of animal farm possessing antimicrobial activity against gram positive and gram negative indicator bacteria was undertaken. Soil provides a natural habitat to bacteria and research shows that it is the well-reported resource for diverse microbiota [14]. Soil samples were collected in sterile conditions from twelve different regions of India (table 1). The colonies (231) obtained on the MRS agar plate were streaked again and transferred into MRS broth for isolating pure culture. These bacteria were initially screened for inhibition activity against $S$. epidermidis by checkerboard dilution method and 30 strains were selected for further study.

Table 1: Soil samples collected from different regions of India

\begin{tabular}{llll}
\hline Sample no. & Collection site & Total isolates & Isolates with antimicrobial activity \\
\hline 1 & Ghaziabad (U. P.) & 26 & 1 \\
2 & Ghazipur (Delhi) & 33 & 10 \\
3 & Gurgaon (Haryana) & 12 & 2 \\
4 & Bijnor (U. P.) & 19 & 4 \\
5 & Agra (U. P.) & 17 & 3 \\
6 & Mathura (U. P.) & 35 & 9 \\
7 & Bulandsahar (U. P.) & 17 & 1 \\
8 & Faridabad (Haryana) & 22 & 0 \\
9 & Dehradun (Uttaranchal) & 24 & 0 \\
10 & Sirdi (Maharastra) & 14 & 0 \\
11 & Bhopal (M. P.) & 17 & 0 \\
12 & Sikar (Rajasthan) & 12 & 0 \\
Total & & 231 & 30 \\
\hline
\end{tabular}

\section{Antimicrobial spectrum of cell free supernatant of selected strains}

Antimicrobial activity of screened bacterial CFS was examined further against $P$. fluorescence, M. luteus and $E$. coli indicator organisms by 96 well microtiter plate assay to select the isolate possessing the broad range antimicrobial activity. The results of checker board assay indicates that 28 out of 30 strains showed $>90 \%$ inhibition against $E$. coli, whereas 20 out of 30 showed inhibition of $P$. fluorescence cells and 19 strains were active against $M$. luteus (table 2 ). In totality 10 strains showed $>90 \%$ inhibition against all chosen bacteria.

\section{Determination of $\mathrm{AU} / \mathrm{ml}$}

The $\mathrm{AU} / \mathrm{ml}$ of CFS from all selected bacterial strains was checked against $S$. epidermidis as indicator organism (table 2). The activity ranged from 80 to $800 \mathrm{AU} / \mathrm{ml}$ and the highest activity was observed for GAS 101 strain up to $800 \mathrm{AU} / \mathrm{ml}$ against S. epidermidis.

\section{Antibiofilm activity of cell free supernatant}

The antibiofilm activity of all the selected strains (30) after initial screening was checked against $S$. epidermidis biofilm. The capability of $S$. epidermidis to produce biofilm was checked on the congo red agar (data not shown). S. epidermidis is an opportunistic dermal pathogen which can cause infections on indwelling medical devices and surgical wounds by forming biofilm [15]. The capability of $S$. epidermidis to form biofilm complicates its removal as it is more resilient to eradication [16]. In the current study, the curing i.e. biofilm disruption as well as the preventive prospective, especially inhibition of biofilm formation, was investigated. Ten out of 30 chosen stains were potentially able to inhibit $>90 \%$ S. epidermidis biofilm formation upon CFS incubation (table 2) and 4 strains could demolish the preformed biofilm by S. epidermidis.

\section{Molecular characterization of potential candidate}

The isolate which displayed antimicrobial activity against all selected strains, antibiofilm activity (formation and disruption) against $S$. epidermidis and demonstrated highest $\mathrm{AU} / \mathrm{ml}$ was selected for molecular characterisation. The 16S ribosomal DNA was amplified by 16S universal primers and its DNA was sequenced for strain identification. The strain (GAS 101) was identified as B. subtilis strain and 16S rDNA partial sequence was submitted to GenBank (accession no. KJ564301). The phylogenetic tree of amplified sequence of $16 \mathrm{~S}$ rDNA was constructed and it showed high similarity with earlier submitted sequences of Bacillus subspecies (fig. 1). 
Table 2: Brief summary of antimicrobial activity of cell free supernatant of isolates against various indicator organisms by the microtiter plate based antimicrobial assay and antibiofilm activity against $S$. epidermidis by crystal violet assay. Each value represents mean of three independent experiments carried out in triplicates $\pm S$. E., where $n=3$

\begin{tabular}{|c|c|c|c|c|c|c|c|c|}
\hline $\begin{array}{l}\text { S. } \\
\text { No. }\end{array}$ & $\begin{array}{l}\text { Isolate } \\
\text { name }\end{array}$ & $\begin{array}{l}\text { \% inhibition } \\
\text { against } S \text {. } \\
\text { epidermidis } \\
\text { MTCC } 435\end{array}$ & $\begin{array}{l}\% \\
\text { inhibition } \\
\text { againstE. } \\
\text { coli MTCC } \\
443\end{array}$ & $\begin{array}{l}\% \\
\text { inhibition } \\
\text { against } P \text {. } \\
\text { fluorescence } \\
\text { MTCC } 2421\end{array}$ & $\begin{array}{l}\% \\
\text { inhibition } \\
\text { against } M . \\
\text { luteus } \\
\text { MTCC } 106\end{array}$ & $\begin{array}{l}\text { \% inhibition of } S \text {. } \\
\text { epidermidis } \\
\text { biofilm formation }\end{array}$ & $\begin{array}{l}\text { \% inhibition of } \\
\text { preformed } S \text {. } \\
\text { epidermidisbiofilm }\end{array}$ & $\begin{array}{l}\mathrm{AU} / \mathrm{ml} \\
\text { against } S \text {. } \\
\text { epidermidis }\end{array}$ \\
\hline 1 & GAS101 & $99.06 \pm 0.3$ & $99 \pm 0.6$ & $99.01 \pm 0.2$ & $99.05 \pm 0.1$ & $99.3 \pm 0.1$ & $96.99 \pm 0.3$ & 800 \\
\hline 2 & GAS 201 & $98 \pm 0.6$ & $94 \pm 0.3$ & $13.7 \pm 0.1$ & $98.1 \pm 0.3$ & $95.13 \pm 0.4$ & $97.04 \pm 0.5$ & 80 \\
\hline 3 & GAS 203 & $97.55 \pm 0.6$ & $92.45 \pm 0.7$ & $15.39 \pm 0.3$ & $97.55 \pm 0.5$ & $89.58 \pm 0.4$ & $20.13 \pm 0.7$ & 80 \\
\hline 4 & GAS 204 & $93.39 \pm 0.5$ & $91.21 \pm 0.5$ & $11.01 \pm 0.1$ & $98.39 \pm 0.6$ & $17.59 \pm 0.5$ & $20.12 \pm 0.6$ & 160 \\
\hline 5 & GAS 205 & $90.99 \pm 0.1$ & $86.91 \pm 0.7$ & $10.03 \pm 0.5$ & $94.99 \pm 0.3$ & $16.02 \pm 0.7$ & $4.03 \pm 0.4$ & 80 \\
\hline 6 & GAS 206 & $94.63 \pm 0.2$ & $91.28 \pm 0.2$ & $13.56 \pm 0.4$ & $96.63 \pm 0.2$ & $1.04 \pm 0.3$ & $4.86 \pm 0.6$ & 80 \\
\hline 7 & GAS 207 & $96.43 \pm 0.5$ & $91.73 \pm 0.3$ & $21.1 \pm 0.6$ & $97.43 \pm 0.5$ & $8.7 \pm 0.5$ & $21.04 \pm 0.3$ & 80 \\
\hline 8 & GAS 209 & $97.61 \pm 0.1$ & $90.68 \pm 0.3$ & $11.23 \pm 0.4$ & $98.61 \pm 0.2$ & $12.57 \pm 0.1$ & $28.47 \pm 0.2$ & 160 \\
\hline 9 & GAS 210 & $96.87 \pm 0.8$ & $91.67 \pm 0.1$ & $10.02 \pm 0.3$ & $97.87 \pm 0.9$ & $97.36 \pm 0.3$ & $21.52 \pm 0.4$ & 320 \\
\hline 10 & GAS 211 & $98.65 \pm 0.4$ & $92.65 \pm 0.8$ & $3.65 \pm 0.7$ & $98.65 \pm 0.7$ & $93.23 \pm 0.5$ & $12.5 \pm 0.7$ & 80 \\
\hline 11 & GAS 212 & $94.67 \pm 0.1$ & $95.87 \pm 0.8$ & $94.67 \pm 0.7$ & $96.67 \pm 0.6$ & $1.04 \pm 0.6$ & $7.02 \pm 0.5$ & 160 \\
\hline 12 & GAS 301 & $92.88 \pm 0.3$ & $84.88 \pm 0.6$ & $84.77 \pm 0.8$ & $94.88 \pm 0.3$ & $82.12 \pm 0.4$ & $70.07 \pm 0.5$ & 640 \\
\hline 13 & GAS 302 & $95.59 \pm 0.3$ & $94.59 \pm 0.3$ & $97.39 \pm 0.7$ & $96.59 \pm 0.8$ & $94.67 \pm 0.6$ & $26.19 \pm 0.7$ & 640 \\
\hline 14 & GAS 402 & $91.55 \pm 0.8$ & $91.55 \pm 0.5$ & $94.65 \pm 0.4$ & $94.55 \pm 0.1$ & $10.87 \pm 0.4$ & $9.05 \pm 0.5$ & 80 \\
\hline 15 & GAS 403 & $93.33 \pm 0.6$ & $92.33 \pm 0.2$ & $93.33 \pm 0.3$ & $95.33 \pm 0.5$ & $85.87 \pm 0.3$ & $17.86 \pm 0.4$ & 80 \\
\hline 16 & GAS 409 & $94.57 \pm 0.3$ & $95.33 \pm 0.3$ & $94.41 \pm 0.4$ & $96.57 \pm 0.6$ & $10.85 \pm 0.5$ & $9.04 \pm 0.6$ & 80 \\
\hline 17 & GAS 413 & $95.95 \pm 0.2$ & $93.47 \pm 0.6$ & $96.48 \pm 0.5$ & $97.95 \pm 0.3$ & $14.52 \pm 0.3$ & $9.01 \pm 0.1$ & 80 \\
\hline 18 & GAS 503 & $96.79 \pm 0.6$ & $95.39 \pm 0.5$ & $97.41 \pm 0.1$ & $11.37 \pm 0.1$ & $17.42 \pm 0.4$ & $13.7 \pm 0.5$ & 80 \\
\hline 19 & GAS504 & $96.89 \pm 0.4$ & $94.65 \pm 0.1$ & $97.39 \pm 0.6$ & $16.44 \pm 0.6$ & $3.21 \pm 0.3$ & $13.5 \pm 0.1$ & 160 \\
\hline 20 & GAS505 & $93.58 \pm 0.3$ & $94.78 \pm 0.3$ & $96.53 \pm 0.7$ & $96.58 \pm 0.8$ & $93.27 \pm 0.2$ & $23.05 \pm 0.7$ & 160 \\
\hline 21 & GAS601 & $94.59 \pm 0.1$ & $95.43 \pm 0.1$ & $95.51 \pm 0.4$ & $96.59 \pm 0.5$ & $93.21 \pm 0.3$ & $23.01 \pm 0.5$ & 160 \\
\hline 22 & GAS 602 & $94.89 \pm 0.1$ & $94.89 \pm 0.3$ & $95.81 \pm 0.3$ & $12.36 \pm 0.4$ & $2.01 \pm 0.1$ & $6.43 \pm 0.4$ & 80 \\
\hline 23 & GAS 603 & $91.55 \pm 0.3$ & $92.55 \pm 0.7$ & $94.75 \pm 0.1$ & $14.37 \pm 0.1$ & $92.72 \pm 0.4$ & $15.91 \pm 0.6$ & 80 \\
\hline 24 & GAS604 & $90.67 \pm 0.5$ & $91.89 \pm 0.1$ & $95.57 \pm 0.2$ & $11.33 \pm 0.7$ & $1.17 \pm 0.3$ & $7.79 \pm 0.7$ & 160 \\
\hline 25 & GAS605 & $90.79 \pm 0.4$ & $91.88 \pm 0.2$ & $95.19 \pm 0.5$ & $15.21 \pm 0.2$ & $99.02 \pm 0.5$ & $12.74 \pm 0.9$ & 160 \\
\hline 26 & GAS606 & $97.65 \pm 0.2$ & $95.15 \pm 0.8$ & $96.45 \pm 0.6$ & $12.24 \pm 0.5$ & $96.04 \pm 0.2$ & $19.06 \pm 0.2$ & 80 \\
\hline 27 & GAS607 & $94.65 \pm 0.1$ & $95.65 \pm 0.7$ & $95.05 \pm 0.5$ & $11.27 \pm 0.7$ & $4.03 \pm 0.1$ & $90.05 \pm 0.6$ & 160 \\
\hline 28 & GAS608 & $92.63 \pm 0.3$ & $93.63 \pm 0.6$ & $96.33 \pm 0.7$ & $14.52 \pm 0.3$ & $20.97 \pm 0.4$ & $8.03 \pm 0.5$ & 80 \\
\hline 29 & GAS609 & $95.46 \pm 0.5$ & $95.46 \pm 0.6$ & $96.66 \pm 0.8$ & $12.35 \pm 0.2$ & $20.77 \pm 0.3$ & $15.73 \pm 0.1$ & 160 \\
\hline 30 & GAS 701 & $97.54 \pm 0.6$ & $95.54 \pm 0.2$ & $95.5 \pm 0.1$ & $13.36 \pm 0.7$ & $2.64 \pm 0.5$ & $99.02 \pm 0.4$ & 80 \\
\hline
\end{tabular}

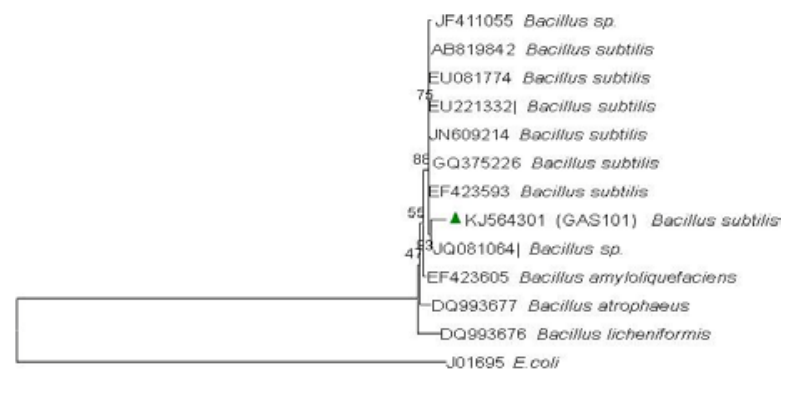

Fig. 1: Phylogenetic tree of partial sequence of 165 rDNA amplified from isolated B. subtilis GAS101 (KJ564301) constructed by Clustal W showing similarity with closely related Bacillus subspecies

\section{DISCUSSION}

Soil typically contains $10^{9}$ to $10^{10}$ microorganisms per gram (dry weight) which may represent more than a million bacterial species [17]. Soil from animal farm remains rich in straw, dung, urine and traces of raw milk, all of these provide an absolute atmosphere to cultivate. Serially diluted soil sample was allowed to grow on the MRS agar plate. MRS agar is a selective medium containing sodium acetate which suppresses the growth of other competing bacterial group and favours the growth of lactic acid bacteria group and Bacillus species [18]. In preliminary selection, S. epidermidis was used as an indicator organism which is an opportunistic pathogen reported for causing infection. In the current study 30 isolates out of 231 showed $>90 \%$ inhibition against $S$. epidermidis and were further screened for broad range antibacterial activity. Other indicator organisms used in the current study belong to gram positive (M. luteus) and gram negative (E. coli and P. fluorescence) clan and have been reported to cause nosocomial infection $[16,19$ 21]. These infections persist and are resilient to antibiotic treatment. Ten strains showed $>90 \%$ inhibition against indicator organisms in the current study which indicates towards the broader range of growth restriction. Nisin, Type A (I) lantibiotic, is FDA approved and has GRAS status which can restrict the growth of both gram positive and gram negative disease causing bacteria. Though nisin is approved as food biopreservative, it has proved its potential for other biomedical applications as well [22]. Apart from LAB, antimicrobial substance from $B$. subtilis has also been reported against the broader range of bacteria inclusive of Salmonella, Bacillus cereus and Staphylococcus aureus [23]. B. subtilis can produce wide array of antimicrobial substances having varied biochemical and biological properties.

S. epidermidis has the ability to colonize on the hospital device and form biofilm. Biofilm is multicellular, surface-attached film which provides architecture to microorganisms that contribute to resistance to antibiotics [16]. In the current study, two strains namely GAS 101 and GAS 301 demonstrated broad range antibacterial activity and in addition were able to inhibit $S$. epidermidis biofilm formation and showed disruption of biofilm. The molecular identification of strain GAS 101, with broader range of antimicrobial activity and highest (800) $\mathrm{AU} / \mathrm{ml}$ against S. epidermidis showed this strain to be B. subtilis. CFS from isolated B. subtilis in the current study showed $800 \mathrm{AU} / \mathrm{ml}$ against $S$. epidermidis whereas Cerein 8A, isolated from Bacillus species, was reported to have 400 $\mathrm{AU} / \mathrm{ml}$ against Listeria monocytogenes [24]. BLIS extracted from $B$. subtilis BS 15 against B. cereus showed $100 \mathrm{AU} / \mathrm{ml}$ [25].

The chance of developing resistance to bacteriocins due to their diverse mechanism of action is less as compared to antibiotics [26]. Despite the huge potential, there are few reports available where 
antimicrobial substances obtained from $B$. subtilis have been targeted against biofilm. Members of Bacillus group are considered good producers of diverse antimicrobial substances, including peptide, lipopeptide antibiotics and bacteriocins [6]. Bacteriocin from Bacillus species are of interest because of their broader range of activity including Gram negative bacteria and fungi [27]. Bacteriocin like inhibitory substance from Bacillus species has been reported for its antimicrobial activity and antibiofilm potential [28]. Sonorensin, a bacteriocin isolated from marine isolate Bacillus sonorensis, has exhibited S. aureus biofilm inhibition and since it could target both multiplying and non-multiplying bacteria, the resistance could not be developed against it [29]. Lipopeptides isolated from $B$. subtilis have shown the reduction in biofilm formation by $88 \%$ and dispersion of mature biofilm by $81 \%$ [30].

\section{CONCLUSION}

Aim of the current study was to isolate the strain with antimicrobial and antibiofilm potential against causative agents of nosocomial infection. Soil samples were collected from animal farm of twelve different regions. Total 231 isolates were preliminary screened against S. epidermidis and 30 isolates exhibiting more than $90 \%$ antimicrobial activity were selected. Selected strains were checked for their broader range of activity and the antibiofilm potential against $S$. epidermidis biofilm. Only one potential strain out of 30 showed $>99 \%$ inhibition against all indicator organism with highest activity unit $(800 \mathrm{AU} / \mathrm{ml})$ against $S$. epidermidis. Molecular characterization by $16 \mathrm{~S}$ rDNA sequencing of this strain showed it to be $B$. subtilis. In summary, antimicrobial substance isolated from the Bacillus species is a potential candidate as an antimicrobial and antibiofilm agent.

\section{ACKNOWLEDGEMENT}

We thank the Department of Biotechnology, Jaypee Institute of Information Technology, Noida, UP, India, for providing the infrastructural facility to carry out the research work.

\section{CONFLICT OF INTERESTS}

There is no conflict of interest

\section{REFERENCES}

1. Inweregbu K, Dave J, Pittard A. Nosocomial infections. Contin Educ Anaesth Crit Care Pain 2005;5:14-7.

2. Cotter PD, Ross RP, Hill C. Bacteriocins-a viable alternative to antibiotics? Nat Rev Microbiol 2013;11:95-105.

3. James R, Penfold CN, Moore GR, Kleanthous C. Killing of E. coli cells by E group nuclease colicins. Biochimie 2002;84:381-9.

4. Rajaram G, Manivasagan P, Thilagavathi B, Saravanakumar A Purification and characterization of a bacteriocin produced by Lactobacillus lactis isolated from marine environment. Adv J Food Sci Technol 2010;2:138-44.

5. Vamanu E, Vamanu A. Viability of the Lactobacillus rhamnosus IL1 strain in simulated gastrointestinal conditions. Int J Pharmacol 2010;16:732-7.

6. Stein T. Bacillus subtilis antibiotics: structures, syntheses and specific functions. Mol Microbiol 2005;56:845-57.

7. Bizani D, Motta AS, Morrissy JA, Terra R, Souto AA, Brandelli A. Antibacterial activity of cerein $8 \mathrm{~A}$, a bacteriocin-like peptide produced by Bacillus cereus. Int Microbiol 2010;8:125-31.

8. Xie J, Zhang R, Shang C, Guo Y. Isolation and characterization of a bacteriocin produced by an isolated Bacillus subtilis LFB112 that exhibits antimicrobial activity against domestic animal pathogens. Afr J Biotechnol 2009;8:5611-9.

9. Teixeira ML, Dalla RA, Brandelli A. Characterization of an antimicrobial peptide produced by Bacillus subtilis subsp. spizezinii showing inhibitory activity towards Haemophilus parasuis. Microbiology 2013;159:980-8.

10. CLSI. Methods for dilution antimicrobial susceptibility tests for bacteria that grow aerobically. M7-A8. CLSI, Wayne, PA; 2009.

11. Ivanova I, Kabadjova P, Pantev A, Danova S, Dousset X. Detection, purification and partial characterization of a novel bacteriocin Substance produced by Lactoccous lactis subsp. lactis b14 isolated from Boza-Bulgarian traditional cereal beverage. Biocatalysis 2004;6:47-53.

12. Sharma G, Raturi K, Dang S, Gupta S, Gabrani R. Combinatorial antimicrobial effect of curcumin with selected phytochemicals on Staphylococcus epidermidis. J Asian Nat Prod Res 2014;16:535-41.

13. Cullings KW. Design and testing of a plant-specific PCR primer for ecological and evolutionary studies. Mol Ecol 1992;1:233-40.

14. Maleki H, Dehnad A, Hanifian S, Khani S. Isolation and molecular identification of Streptomyces spp. with antibacterial activity from northwest of Iran. Biol Impacts 2013;3:129-34.

15. Ziebuhr W, Hennig S, Eckart M, Kränzler H, Batzilla C, Kozitskaya S. Nosocomial infections by Staphylococcus epidermidis: how a commensal bacterium turns into a pathogen. Int J Antimicrob Agents 2006;28:14-20.

16. Otto M. Staphylococcus epidermidis-the accidental pathogen. Nat Rev Microbiol 2009;7:555-67.

17. Eichorst SA, Breznak JA, Schmidt TM. Isolation and characterization of soil bacteria that define Terriglobus gen. nov., in the phylum Acidobacteria. Appl Environ Microbiol 2007;73:2708-17.

18. Mahrous H, Mohamed A, El-Mongy MA, El-Batal AI, Hamza HA. Study bacteriocin production and optimization using new isolates of Lactobacillus spp. isolated from some dairy products under different culture conditions. J Nutr Food Sci 2013;4:342.

19. Tagoe DNA, Baidoo SE, Dadzie I, Tengey D. Potential sources of transmission of hospital acquired infections in the volta regional hospital in Ghana. Ghana Med J 2011;45:22-6.

20. Obritsch MD, Fish DN, MacLaren R, Jung R. Nosocomial infections due to multidrug-resistant Pseudomonas aeruginosa: epidemiology and treatment options. J Pharmacother 2005;25:1353-64.

21. Bonjar S. Evaluation of antibacterial properties of some medicinal plants used in Iran. J Ethnopharmacol 2004;94:301-5.

22. Shin JM, Gwak JW, Kamarajan P, Fenno JC, Rickard AH, Kapila YL. Biomedical applications of nisin. J Appl Microbiol 2016;1201:1449-65.

23. Wu S, Jia S, Sun D, Chen M, Chen X, Zhong J, et al. Purification and characterization of two novel antimicrobial peptides subpeptin JM4-A and subpeptin JM4-B produced by Bacillus subtilis JM4. Curr Microbiol 2005;51:292-6.

24. Bizani D, Motta AS, Morrissy JA, Terra RM, Souto AA, Brandelli A. Antibacterial activity of cerein $8 \mathrm{~A}$, a bacteriocin-like peptide produced by Bacillus cereus. Int Microbiol 2005;8:125-31.

25. Alam SI, Kamran M, Sohail M, Ahmad A, Khan AK. Partial characterization of bacteriocin like inhibitory substance from bacillus subtilis BS15, a local soil isolate. Pak J Bot 2011:43:2195-9.

26. Guilhelmelli F, Vilela N, Albuquerque P, Derengowski LD, SilvaPereira I, Kyaw C. In: Nadia SP, Octavio LF. editors. New edge of antibiotic development: antimicrobial peptides and corresponding resistance. Switzerland: Frontiers Media SA; 2013. p. 63.

27. Abriouel H, Franz CM, Omar NB, Gálvez A. Diversity and applications of Bacillus bacteriocins. FEMS Microbiol Rev 2011;35:201-32.

28. Korenblum E, Sebastián GV, Paiva MM, Coutinho CM, Magalhães FC, Peyton BM, et al. Action of antimicrobial substances produced by different oil reservoir Bacillus strains against biofilm formation. Appl Microbiol Biotechnol 2008;79:97-103.

29. Chopra L, Singh G, Jena KK, Sahoo DK. Sonorensin: a new bacteriocin with potential of an anti-biofilm agent and a food biopreservative. Sci Rep 2015;21:5.

30. Moryl M, Spętana M, Dziubek K, Paraszkiewicz K, Różalska S, Płaza GA, et al. Antimicrobial, antiadhesive and antibiofilm potential of lipopeptides synthesised by Bacillus subtilis, on uropathogenic bacteria. Acta Biochim Pol 2014;62:725-32.

\section{How to cite this article}

- Garima Sharma, Shweta Dang, Sanjay Gupta, Reema Gabrani. Identification and molecular characterization of bacteria having antimicrobial and antibiofilm activity. Int J Pharm Pharm Sci 2016;8(10):111-114. 